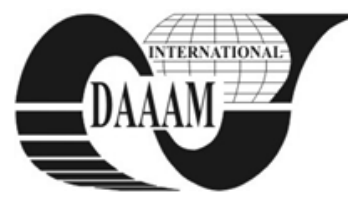

Annals of DAAAM for 2011 \& Proceedings of the 22nd International DAAAM Symposium, Volume 22, No. 1, ISSN 1726-9679 ISBN 978-3-901509-83-4, Editor B. Katalinic, Published by DAAAM International, Vienna, Austria, EU, 2011 Make Harmony between Technology and Nature, and Your Mind will Fly Free as a Bird Annals \& Proceedings of DAAAM International 2011

\title{
GENERATION Y IN MARKETING
}

CAMBAL, M[ilos] \& VASKOVICOVA ZIBRINOVA, E[va]

\begin{abstract}
Nowadays we are experiencing unstoppable evolution where the changing of generations becomes evident. The entering of a new generation can be characterized as the arrival of so called generation $Y$. There is an important challenge standing in front of entrepreneurs and more significantly marketers; to address this potential group of customers. This requires the utilization of new communication paths and optimal forms of communication. This article deals with the definitions of the characteristics of the generation $Y$ members and the projection of promotion parameters influencing the generation $Y$
\end{abstract}

Key words: marketing, advertisement, communication, generation $Y$

\section{INTRODUCTION}

Digital culture, described by rapid emergence of new information technologies, is what is typical for the current young generation. Every day they are surrounded by modern technologies, devices and inventions. Through amenities such as cells phones and internet they can perform their tasks anywhere and at anytime. This generation of young people is no more bound by working hours and premises; it rather creates new communities on social networks online. These are the basic attributes of the generation $Y$ that surrounds us. Marketers and managers are now looking for ways how to succeed with regards to this new young generation. The problem with marketing is becoming a well defined Generation Y, marketing communications and adjust for these potential consumers.

\section{CHARACTERISTICS OF GENERATION Y}

Term "generation Y" was created in the USA to describe a generation entering the market that is characterized by a certain consumer behavior and certain style of living. Generation $\mathrm{Y}$ is often labeled as web generation, net generation, or echo boomers. With regards to marketing, term generation $\mathrm{Y}$ is used to describe consumers of a certain category, for whom it is necessary to create propagation and brand with significant character. Members of the generation $\mathrm{Y}$ are consumers born between 1977 and 1995. (Múčka 2007)

In order to define the characteristics of the consumers of generation $\mathrm{Y}$, whose members operate on Slovak market, a research was conducted by the Institute of Industrial Engineering, Management and Quality MTF from January until July 2011 on a sample of industrial enterprises acting in Slovak Republic. This research focused on the behavior and lifestyle of the young generation. Specifically examined were the motivators stimulating their purchasing behavior.

Information obtained from research led to the defining characteristics of consumers of Generation Y, this information can be compiled characteristics of the young generation of consumers. The consumers of this generation are characterized by the utilization of internet and modern technologies, through which they acquire huge amount of information about products. A sense of practicality is an important feature of generation Y.

Members of generation $\mathrm{Y}$ also:

- don't believe in traditional promotion,

- process larger amounts of information compared to previous generation,

- have high expectations from life,

- have a relationship to services, internet and technologies,

- rely on themselves,

- are ambitious, confident and independent,

- $\quad$ are competitive and strive success

- love challenges and hate stereotypes,

- $\quad$ are losing loyalty to trademarks

- carrier and salary growth are considered a platitude,

- require more freedom and flexible working hours,

- have higher appreciation for their own value,

- and contact and the creation of communities are a lifestyle.

Overview of the generation Y:

Requirement for product:

- $\quad$ interesting,

- $\quad$ practical and expressing information,

- enabling communication,

- $\quad$ taking into account the trends.

Resources:

- knowledge,

- $\quad$ experience,

- design, finance,

- information technology proficiency.

Members of generation $\mathrm{Y}$ are significantly different from the generation of their parents, they long for success and realize that there is no social institution to take care of their future. (Múčka 2007)

As means to achieve their goals they consider education, finance proficiency, knowledge of information technologies and last but not least, appearance. (Zelník 1999) It's these features that make them interesting and exceptional.

\section{CHARACTERISTICS OF EFFECTIVE ADVERTISEMENT}

Group of people called "generation Y" grew up surrounded by advertisement and expensive labels. Thanks to this fact, today they do not trust advertisements nor trademarks. They try to identify themselves with such products that fit and express their lifestyle.

Generation Y lives for advertisement and therefore cannot be cheated. Promotion plays no role in affecting their 
purchasing behavior. (Voluščukova 2003) Crucial is to define characteristics of marketing communication that influences potential customers.

Means of marketing communication that appropriately motivate consumers contribute to the achievement of the strategic goals of an enterprise.

In order to correctly motivate and influence generation $\mathrm{Y}$ in their decision-making about purchasing of products, advertisement needs to bear the following attributes:

- practical and clear information,

- humorous undertone

- design focused,

- good preparation, no underestimation of details,

- the highlighting of product, product $=$ means of communication

- focusing on the lifestyle of generation Y,

- $\quad$ and common creation of trademark.

Advertisement aimed for young people should not include marketing activities such as presentation of products by personalities and features such as simplicity and sternness.

Design plays a crucial role in advertising, and also mobile marketing found an important place among communication tools of the selected mixture. The life of generation $\mathrm{Y}$ is strongly influenced by information and communication technologies. When creating advertisements, it is vital to consider the fact that nowadays everything can be quickly verified. Young people exist in communities where it is easy to find someone who has experience with the product. (Voluščukova 2003)

It is prominent for generation $\mathrm{Y}$ to process information in a different way. Through multimedia and sensual acts, this group became used to graphics and audio effects. It prefers movement, dynamics and music. It is the so called key triangle of "PICTURE - SOUND - MUSIC" that influences the young generation. (Psychológia a sociológia trhu 2009)

Marketers adjust their attitude, they no longer perceive generation $\mathrm{Y}$ as children. Enterprises also realize that if they do not change the practice of marketing communication, they will lose customers. Marketing of the generation Y requires absolute subordination to the emerging generation of consumers. Nowadays, marketing is focused on customers in their productive age who dispose of financial means.

The age and situation are changing, young people are becoming purchase effective, they love labels and are becoming strong consumers on the market. This reality cannot be ignored.

Good and working marketing strategy needs to look for basis among the needs and requirements of young people, it has to perceive their lifestyle and adjust to it. Products have to be practical, sophisticated, well designed, interesting, they need to represent certain idea. They need to be trendy.

Along the evolution of information and communication technologies, trends and products attractive for this generation change as well. Producers therefore need to consider that what is "in" today, will be replaced by something new tomorrow. Producers need to adjust to this reality; they need to be prepared for it. (Zelník 1999)

In order to forge appropriate marketing communication, it is necessary to realize that generation $\mathrm{Y}$ is not created by a homogenous group of people. It is vital to constantly search for and discover new forms and ways of how to address potential customers. (Generácia Y hl'adá na webe, 2008)

Internet marketing (or internet advertisement) has become an appropriate means of marketing communication mix. Internet allows different groups of people to access information. Internet offers two-way communication.
Communication via chats and forums is created between an enterprise offering advertisement and information on one side, and potential customer on the other. This is the place for dialogue for the two. Internet advertisement is therefore becoming popular and successful. Different forms of "modern" advertisement don't bring any feedback; they are not interesting for generation $\mathrm{Y}$ and thus are becoming ineffective for enterprises. (Psychológia a sociológia trhu 2009)

\section{CONCLUSION}

We can ascertain that even though young people in Slovakia are claimed to be members of generation $\mathrm{Y}$, in their purchase decisions they use different purchase procedures and models. (Zelník 1999) This forces marketers to think about new tools of marketing communication.

Marketing communication of generation $\mathrm{Y}$ is becoming by means the copying of image of the famous and rich people, who represent individuality and uniqueness in the young world. Therefore their lifestyle and preferred products are becoming so called generation symbols. (Psychológia a sociológia trhu 2009)

Despite these facts, it is important for enterprises to adjust used marketing tools to actual conditions of the environment they act upon.

During planning and implementation of marketing communication in every form, it is necessary to consider demands and privileges of the environment - thus demands and privileges of current generation $\mathrm{Y}$.

Identification of behavior generation $\mathrm{Y}$ and its characteristics are only the beginning of the current planning marketing communications of company. The next step in the development of marketing communication is the correct implementation of research findings advertising elements, which requires the generation $\mathrm{Y}$.

Created marketing communications should include observed characteristics, to ensure its effectiveness. When marketers use research knowledge gained in the development of marketing communication, have a chance to succeed in a competitive struggle to acquire new customers among generationY.

Future research will aim to Determine the effectiveness of "new" marketing communications of Generation Y. Describes the force zvolenýcjh marketingoového mix tools.

\section{REFERENCES}

Generation Y meni vzhl'ad výroby, (2007), Available from: http://www.sme.sk/c/3407406/generaci-y-meni-vyhladvzroby.html: Accessed: 20110810

Generácia Y hl'adá na webe, (2008), Stratégie online Spravodajský portál marketingu, Available from: http://www.strategie.sk/showdoc.do?docid=19014.Accesse d: 20110810

Múčka, F.; (2007). Generation Y tiahne na svet,Available from: http://www.etrend.sk/podnikanie/riadenie-a-

kariera/generation-y-tiahne-na-svet/11736.html: Accessed: 20110810

Psychológia s sociológia trhu, (2009) Available from: http://www.golem.corinex.com/gregi/fmk/rocnik2008/PSM /psychologia: Accessed: 20110810

Valoščuková, D.; (2003) Značky generácie Y Available from: http://www.sme.sk/c/1199135/ynackz-generacie-z.html. Accessed: 20110810

Zelník, R.; (1999). Marketingový oriešok: Generácia Y, Available from: http//mzslienkz.csieti.sk/marketingovoriesok-generacia-z: Accessed: 20110810 